\title{
Antinociceptive Activity of the Novel Fentanyl Analogue iso-Carfentanil in Rats
}

\author{
Sonja Vučković ${ }^{1}$, Milica Prostran ${ }^{1, *}$, Milovan Ivanović ${ }^{2}$, Zorana Ristović ${ }^{3}$ and Radan Stojanović ${ }^{1}$ \\ ${ }^{I}$ Department of Clinical Pharmacology, Pharmacology and Toxicology, School of Medicine, University of Belgrade, \\ Dr Subotića 1, P.O. Box 840, 11129 Belgrade, Yugoslavia \\ ${ }^{2}$ Faculty of Chemistry, University of Belgrade, Studentski trg 12-16, P.O. Box 158, 11001 Belgrade, Yugoslavia \\ ${ }^{3}$ Institute of Oncology and Radiology, Pasterova 14, 11000 Belgrade, Yugoslavia
}

Received April 24, $2000 \quad$ Accepted July 15, 2000

\begin{abstract}
A large number of fentanyl analogues have been synthesized so far, both to establish the structure-activity-relationship (SAR) and to find novel, clinically useful antinociceptive drugs. In this study, the newly synthesized fentanyl analogue 3-carbomethoxy fentanyl (iso-carfentanil) was compared to fentanyl for its antinociceptive activity (tail-immersion test) in rats. It was revealed that the introduction of a 3-carbomethoxy group in the piperidine ring of fentanyl skeleton reduced the potency and shortened the duration of action of the parent compound, i.e., fentanyl. The antinociceptive potency of 3-carbomethoxy fentanyl is influenced mainly by the steric factor (voluminosity of the carbomethoxy group and the cis/trans isomerism), while the chemical nature of the group is probably irrelevant. This is in agreement with SAR studies of other 3-substituted fentanyl analogues. In contrast to potency, the duration of action is not affected by cis/trans isomerism. It is assumed that the time course of action of 3-carbomethoxy fentanyl is influenced by the nature of the carbomethoxy group. Since the potency and the duration of action of this novel antinociceptive compound are interesting from the aspect of SAR studies and have potential promise for clinical application, 3-carbomethoxy fentanyl deserves to be extensively evaluated.
\end{abstract}

Keywords: Antinociception, Fentanyl, Carfentanil, Structure-activity-relationship

Fentanyl (Fig. 1), the prototype of the 4-anilidopiperidine class of synthetic opioid analgesics, is widely and successfully used to supplement general anesthesia or to treat postoperative and cancer pain $(1-3)$. However, like other $\mu$-agonists, fentanyl produces serious adverse effects including respiratory depression, muscle rigidity and on prolonged use, tolerance and addiction. In order to discover an analgesic with an improved pharmacodynamic and pharmacokinetic profile, extensive efforts during last four decades have been devoted to syntheses of a large number of fentanyl analogues and establishing the structure-activity-relationship (SAR) of the 4-anilidopiperidine class of analgesics (4-8). As a result of such efforts, several congeners of fentanyl, alfentanil, sufentanil and remifentanil were discovered and have found clinicaly utility as anesthesia adjuncts $(9-12)$. Several other compounds are still under extensive evaluation in animals nowadays, while some of them are proposed as a useful tools for studying

*Corresponding author. FAX: + 381-11-751-396

E-mail: mprostra@bits.net the opioid receptors $(13-17)$. The availability of this range of synthetic opioids and better understanding of the relationship between their structure and the pharmacokinetic and the pharmacodynamic properties provide greater flexibility and increase safety in the management of pain and stress responses during surgery.

It has been previously demonstrated that antinociceptive potency of the 3-alkyl fentanyl analogues is predominantly influenced by the steric factor; i.e., the voluminosity of the alkyl group and the cis/trans isomerism $(4,18)$. For example, the presence of the methyl group on the piperidine ring in the fentanyl skeleton results in about a tenfold increase in antinociceptive potency, while more voluminous alkyl groups cause a gradual drop in the activity compared to fentanyl itself $(4,18-21)$. Also, the analogues with 3-alkyl groups in the cis position are known to be more potent than the trans isomers $(4,18,20)$.

It has already been reported that fentanyl analogues with relatively small polar groups, such as carbomethoxy or methoxymethyl in position 4 of the piperidine ring, were far more active than the parent compound (22). Thus, 
<smiles>CCC(=O)N(c1ccccc1)C1CCN(CCc2ccccc2)CC1</smiles>

Fentanyl<smiles>CCC(=O)N(c1ccccc1)C1(C(C)=O)CCN(CCc2ccccc2)CC1</smiles>

Carfentanil<smiles>CCC(=O)N(c1ccccc1)[C@H]1CCN(CCc2ccccc2)C[C@H]1C(C)C</smiles>

( \pm ) cis 3-Carbomethoxy fentanyl<smiles>CCC(=O)N(c1ccccc1)[C@H]1CCN(CCc2ccccc2)C[C@H]1C(C)=O</smiles>

( \pm ) trans 3-Carbomethoxy fentanyl

Fig. 1. Chemical structures of fentanyl, carfentanil, $( \pm)$ cis 3-carbomethoxy fentanyl and $( \pm)$ trans 3-carbomethoxy fentanyl.

carfentanil (4-carbomethoxy fentanyl) (Fig. 1) is about thirty times more potent than fentanyl and has been used for immobilization of wild animals $(22-24)$. Lofentanil (the levoantipode of the cis 3-methyl analogue of carfentanil) is approximately five times more potent than fentanyl, with a remarkable long duration of action: however, it does not have clinical significance (25). Contrary to this, sufentanil is of great clinical value due to its high potency, short duration of action and high safety margin $(1,2,9)$.

The objective of SAR studies is to approach the ideal analgesic profile, focusing mainly on potency, safety and duration of action. In view of the interesting SAR that was obtained with 3 -alkyl fentanyl analogues $(4,18)$, as well as analogues substituted at $\mathrm{C}-4$ by a carbomethoxy group (22-25), 3-carbomethoxy fentanyl (iso-carfentanil) (Fig. 1) was synthesized (26) and evaluated for analgesic activity in rats.

\section{MATERIALS AND METHODS}

Wistar rats of either sex $(200-250 \mathrm{~g})$ were used. Prior to each experiment, the animals were habituated to the handling and experimental procedure for three consecutive days ${ }^{1}$. The antinociceptive activity was determined by the tail-immersion test (27). In brief, the rat was placed in a cylindrical rat holder with its tail hanging freely outside the cage. The distal $5 \mathrm{~cm}$ of the tail was immersed in a warm water bath $\left(55 \pm 0.5^{\circ} \mathrm{C}\right)$ and the time for tail-withdrawal was measured as a response latency. To minimize tissue damage by repeated testing, a 10-s cutoff time was imposed for all animals that failed to respond to the stimulus (28). This means that the maximal duration of a single exposure of rat tail to hot water was $10 \mathrm{~s}$. Predrug response latency was obtained $5 \mathrm{~min}$ before i.p. drug administration. Postdrug response latency was measured after i.p. administra-

\footnotetext{
${ }^{1}$ The investigation conforms with the Guide for the Care and Use of Laboratory Animals published by the U.S. National Institute of Health (NIH Publication No. 85-23, revised 1985).
}

tion of test compound at $5,10,15,20$, etc. min. Response latency is expressed as a percent maximum possible effect (\%MPE) and calculated according to the following formula: $\% \mathrm{MPE}=$ (postdrug latency - predrug latency) $/$ (cutoff time - predrug latency) $\times 100$.

Dose-response curves were analyzed by linear regression. The $\mathrm{ED}_{50}$ and $95 \%$ confidence limits were estimated from the dose-response curve by using standard statistical software (29).

Fentanyl citrate (ICN Yugoslavia, Belgrade, Yugoslavia) and $( \pm)$ cis and $( \pm)$ trans 3-carbomethoxy fentanyl oxalate were dissolved in saline and injected i.p. in a final volume

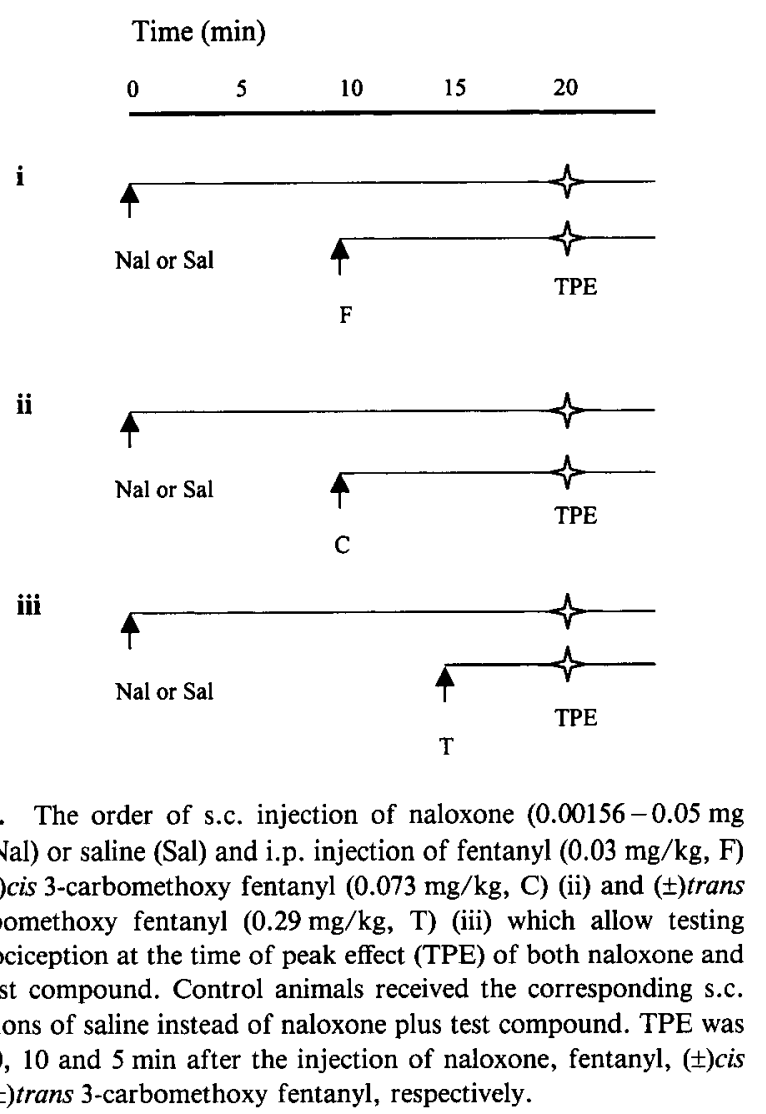

Fig. 2. The order of s.c. injection of naloxone $(0.00156-0.05 \mathrm{mg}$ $/ \mathrm{kg}, \mathrm{Nal})$ or saline (Sal) and i.p. injection of fentanyl $(0.03 \mathrm{mg} / \mathrm{kg}, \mathrm{F})$ (i), $( \pm)$ cis 3-carbomethoxy fentanyl $(0.073 \mathrm{mg} / \mathrm{kg}, \mathrm{C})$ (ii) and ( \pm )trans 3-carbomethoxy fentanyl $(0.29 \mathrm{mg} / \mathrm{kg}, \mathrm{T})$ (iii) which allow testing antinociception at the time of peak effect (TPE) of both naloxone and the test compound. Control animals received the corresponding s.c. injections of saline instead of naloxone plus test compound. TPE was $20,10,10$ and $5 \mathrm{~min}$ after the injection of naloxone, fentanyl, $( \pm$ ) cis and $( \pm$ )trans 3-carbomethoxy fentanyl, respectively. 
of $2 \mathrm{ml} / \mathrm{kg}$ (26). Naloxone hydrochloride (Sigma Chemical Co., St. Louis, MO, USA) was also dissolved in saline and injected s.c. in the back before the i.p. injection of the test compound in the same volume. The order of injections was established on the basis of the time-effect curve and allowed testing antinociception at the time of peak effects of both s.c. naloxone and the i.p. test compound (Fig. 2). Although, naloxone expressed a significant antagonism over the range of $15-25 \mathrm{~min}$ after injection, the peak effect of naloxone occurred $20 \mathrm{~min}$ after its s.c. injection mostly (not shown). This result is in accordance with the previous finding (30). Since we have found that the antinociceptive effects of $\mathrm{ED}_{99}$ of intraperitoneal fentanyl, $( \pm$ ) cis and $( \pm)$ trans 3-carbomethoxy fentanyl peaked at about 10, 10 and $5 \mathrm{~min}$, respectively (Fig. 3: A, B and C), and the peak effect of naloxone occurred $20 \mathrm{~min}$ after its s.c. injection (not shown), naloxone was applied: 10, 10 and $15 \mathrm{~min}$ before the i.p. injection of fentanyl, $( \pm)$ cis and
$( \pm)$ trans 3-carbomethoxy fentanyl, respectively (Fig. 2). Control animals received the corresponding volume of saline (s.c.) instead of naloxone plus test compound. The percent inhibition of responding effects by the naloxone pretreatment was expressed as follows: Percent inhibition of antinociception $=100-[\mathrm{MPE}$ (in the presence of naloxone) / MPE (in the presence of saline) $\times 100$ ] (31).

Dose-response curves were analyzed by linear regression. $\mathrm{ID}_{50}$ (the dose of naloxone that caused a $50 \%$ inhibition of antinociception) with $95 \%$ confidence limits were then calculated and compared (29). To compare time courses of the effects produced by the several drugs, data were expressed as the area under the curve (AUC); e.g., the area of a series of trapezoids in which the height was postdrug response latency minus the predrug response latency (s) and the base, the interval (min) between measurements. This provided an index with the dimension of secondminute (32). The slopes of the regression lines were com-
A

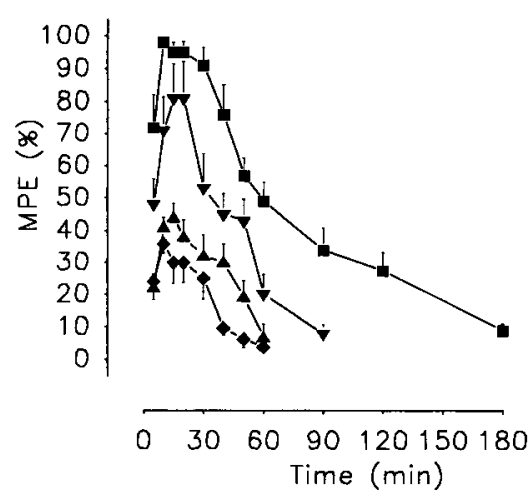

C

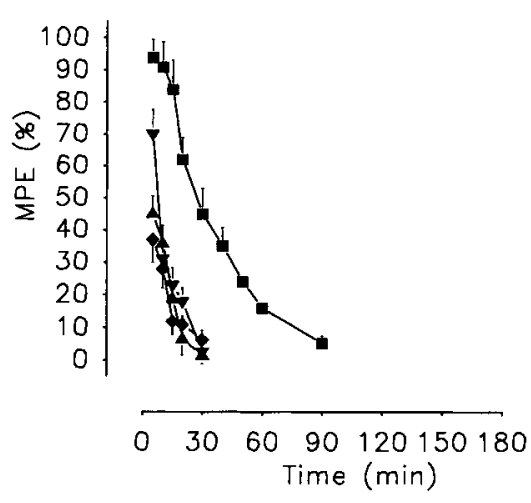

B

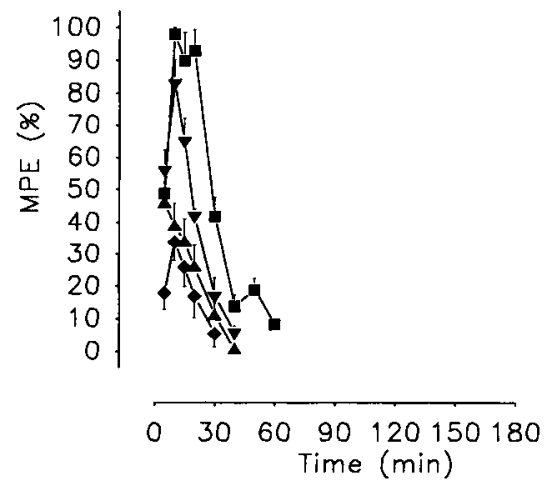

D

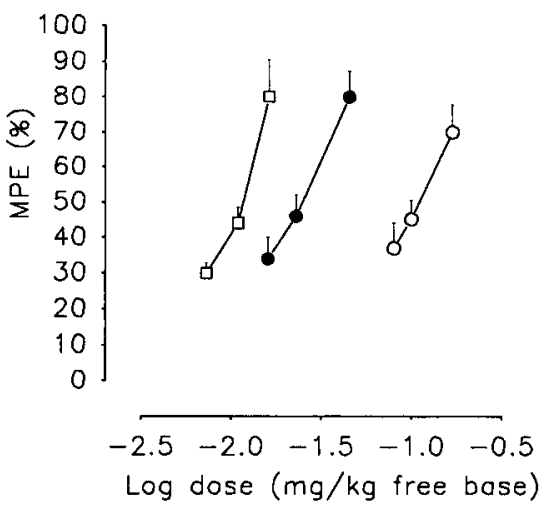

Fig. 3. The time- (A, B and C) and log dose- (D) response curves on the tail immersion for fentanyl (A and D), ( \pm )cis 3-carbomethoxy fentanyl (B and D) and ( \pm )trans 3-carbomethoxy fentanyl (C and D) given i.p. in rats. A: fentanyl $(0.0073 \mathrm{mg} / \mathrm{kg}$, $\triangleleft$; $0.011 \mathrm{mg} / \mathrm{kg}, \boldsymbol{\Delta} ; 0.016 \mathrm{mg} / \mathrm{kg}, \boldsymbol{\nabla} ; 0.030 \mathrm{mg} / \mathrm{kg}, \square) ; B:( \pm)$ cis 3-carbomethoxy fentanyl $(0.016 \mathrm{mg} / \mathrm{kg}, \diamond ; 0.023 \mathrm{mg} / \mathrm{kg}, \boldsymbol{\Delta} ; 0.045$ $\mathrm{mg} / \mathrm{kg}, \nabla ; 0.073 \mathrm{mg} / \mathrm{kg}, \boldsymbol{\nabla}) ; \mathrm{C}:( \pm$ ) trans 3-carbomethoxy fentanyl $(0.08 \mathrm{mg} / \mathrm{kg}, \boldsymbol{\nabla} ; 0.10 \mathrm{mg} / \mathrm{kg}, \boldsymbol{\Delta} ; 0.17 \mathrm{mg} / \mathrm{kg}, \boldsymbol{\nabla} ; 0.29$ $\mathrm{mg} / \mathrm{kg}, \square)$; D: fentanyl $(0.0073-0.016 \mathrm{mg} / \mathrm{kg}, \square),( \pm)$ cis 3 -carbomethoxy fentanyl $(0.016-0.045 \mathrm{mg} / \mathrm{kg}, \bigcirc)$ and $( \pm)$ trans 3 -carbomethoxy fentanyl $(0.08-0.17 \mathrm{mg} / \mathrm{kg}, \bigcirc) . \mathrm{MPE}=$ maximum possible effect. Each point represents the mean \pm S.E.M. of the antinociception in six to eight rats. 
pared by using a test for parallelism (29).

Both $( \pm)$ cis and $( \pm)$ trans 3-carbomethoxy fentanyl were examined as a racemic mixture. Doses of the drugs were calculated for the free base. To test whether saline injection in control rats has any effect on the tail immersion latency, the $t$-test for paired values was used (29). A $P$ value of less than 0.05 was considered statistically significant. Relative potency estimates were considered statistically significant when $95 \%$ confidence limits did not overlap 1.0.

\section{RESULTS}

The i.p. injection of fentanyl, $( \pm)$ cis and $( \pm)$ trans 3-carbomethoxy fentanyl produced a dose-dependent increase in latency of the tail-immersion response generated by highintensity thermal stimuli (Fig. 3: A, B and C). Although all three tested compounds displayed linear dose-response functions, the slopes of $( \pm$ )cis and $( \pm)$ trans 3-carbomethoxy fentanyl were significantly reduced $(P<0.05)$ in comparison with fentanyl (Table 1, Fig. 3D). Based on the $\mathrm{ED}_{50}$ values, the relative order of potency was as follows: fentanyl (1) $\geq( \pm$ ) cis 3-carbomethoxy fentanyl $(0.43)>( \pm)$ trans 3-carbomethoxy fentanyl $(0.095)$ (Table 1$)$.

Maximal antinociceptive responses were obtained 5-10 min after i.p. injection of both isomers of 3-carbomethoxy fentanyl and 10-15 min after i.p. injection of fentanyl (Fig. 3: A, B and C). The duration of the effect produced by all tested compounds was dose-dependent (Fig. 3: A, B and $C$ ). Because doses of the tested compounds given i.p. that produced the same magnitude of response appeared to have different time courses (Fig. 3: A, B and C), we examined the relationship between the MPE produced by a given i.p. dose of a drug and AUC for the associated effect (Table 1). The rank order of the magnitude of the slope of the AUC-MPE plot was: $( \pm$ cis 3-carbomethoxy fentanyl (2.3) $\leq( \pm$ )trans 3-carbomethoxy fentanyl $(2.7)<$ fentanyl (4.1). This indicated that for doses producing comparable effects, $( \pm)$ cis and $( \pm$ )trans 3-carbomethoxy fentanyl displayed significantly $(P<0.05)$ shorter time-courses than fentanyl. Expressed in min, fentanyl, $( \pm)$ cis and $( \pm)$ trans 3 -carbomethoxy fentanyl, exhibited duration of antinociception of 60,30 and $30 \mathrm{~min}$, respectively (time that is necessary for the tail withdrawal response to reduce to $50 \%$ MPE after i.p. injection of equi-effective doses $\left(E D_{99}\right)$ of three tested compounds) (Fig. 3: A, B and C).

Pretreatment of the rats with s.c. naloxone produced a dose-dependent inhibition of the antinociceptive effects produced by the i.p. injection of a maximally effective dose (ED 99$)$ of fentanyl $(0.03 \mathrm{mg} / \mathrm{kg}),( \pm)$ cis 3 -carbomethoxy fentanyl $(0.073 \mathrm{mg} / \mathrm{kg})$ and $( \pm)$ trans 3-carbomethoxy fentanyl $\left(0.29 \mathrm{mg} / \mathrm{kg}\right.$ ) (Fig. 4: A, B, C and D). The $\mathrm{ID}_{50} \mathrm{~s}$ of the three tested compounds were not statistically different $(P>0.05)$ (Table 2).

In control experiments, i.p. injection of saline had no effect on the animal's tail immersion latency $(P>0.05)$; the latencies before and after saline injection were found to be $2.32 \pm 0.32$ and $2.40 \pm 0.25 \mathrm{~s}$, respectively $(\mathrm{n}=8)$ (not shown).

\section{DISCUSSION}

In this study, the newly synthesized fentanyl analogues, $( \pm$ ) cis and $( \pm$ )trans 3-carbomethoxy fentanyl (26) were examined for their antinociceptive activity and compared to fentanyl by the tail-immersion test. It was found that the introduction of a carbomethoxy group in position 3 of the piperidine ring of fentanyl decreased antinociceptive activity by a factor of 2 and 10 in $( \pm)$ cis and $( \pm$ )trans 3 -carbomethoxy fentanyl, respectively. In view of the previous

Table 1. Summary of MPE dose-response curves and AUC-MPE curves for i.p. fentanyl, ( \pm )cis 3-carbomethoxy fentanyl and $( \pm)$ trans 3 -carbomethoxy fentanyl in rats ${ }^{1}$

\begin{tabular}{lccc}
\hline & $\begin{array}{c}\text { Fentanyl } \\
(0.0073-0.016 \mathrm{mg} / \mathrm{kg}) \\
(\mathrm{n}=24)\end{array}$ & $\begin{array}{c}( \pm) \text { cis 3-Carbomethoxy fentanyl } \\
(0.016-0.045 \mathrm{mg} / \mathrm{kg}) \\
(\mathrm{n}=23)\end{array}$ & $\begin{array}{c}( \pm) \text { trans 3-Carbomethoxy fentanyl } \\
(0.08-0.17 \mathrm{mg} / \mathrm{kg}) \\
(\mathrm{n}=20)\end{array}$ \\
\hline MPE dose responses & & & \\
ED $_{50}(\mathrm{mg} / \mathrm{kg})^{2}$ & 0.0104 & 0.024 & $0.109^{*}$ \\
$95 \% \mathrm{CL}$ & $(0.006-0.018)$ & $(0.014-0.040)$ & $(0.086-0.139)$ \\
slope \pm S.E.M. & $145.6 \pm 18.2$ & $103.3 \pm 9.9^{*}$ & $103.1 \pm 6.2^{*}$ \\
r & 0.992 & 0.995 & 0.998 \\
AUC-MPE response & & & \\
slope \pm S.E.M. & $4.1 \pm 0.2$ & $2.3 \pm 0.1^{*}$ & $2.7 \pm 0.07^{*}$ \\
r & 0.999 & 0.998 & 1 \\
\hline
\end{tabular}

${ }^{1}$ Results are summarized from data presented in Fig. 3D. ${ }^{2} \mathrm{ED}_{50}$ s were calculated from three doses of each compound with $6-8$ rats per dose. $n=$ total number of animals employed to produce the respective dose-response curve. $C L=$ confidence limits, $r=$ correlation coefficient, MPE = maximum possible antinociceptive effect, AUC-MPE = area under the curve-maximum possible antinociceptive effect. *Significantly $(P<0.05)$ different in comparison with fentanyl. 
A

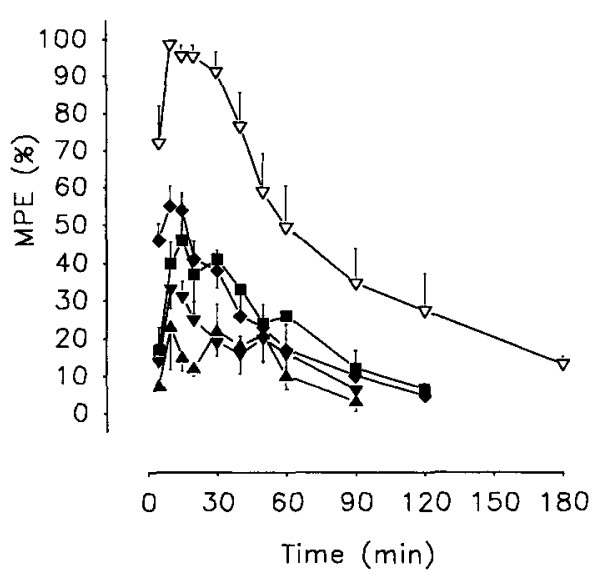

C

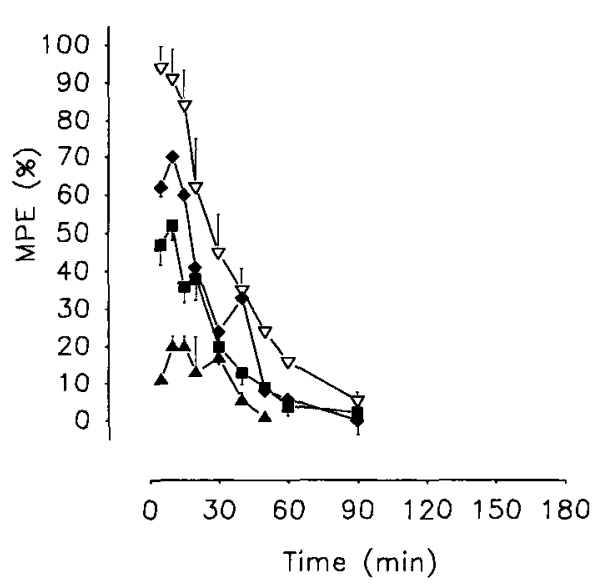

B

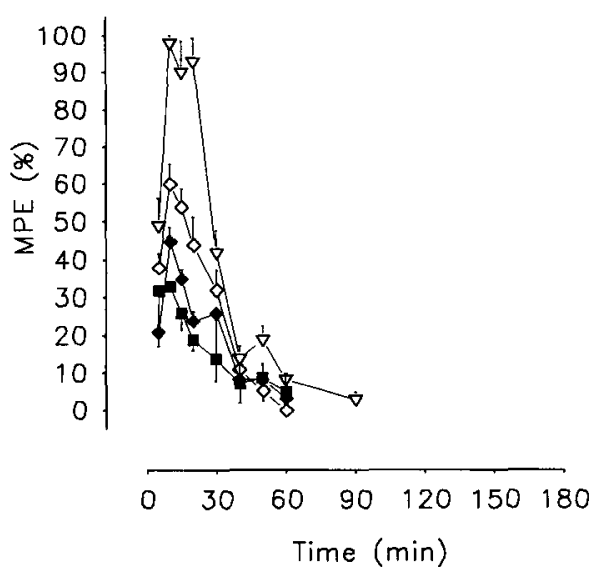

D

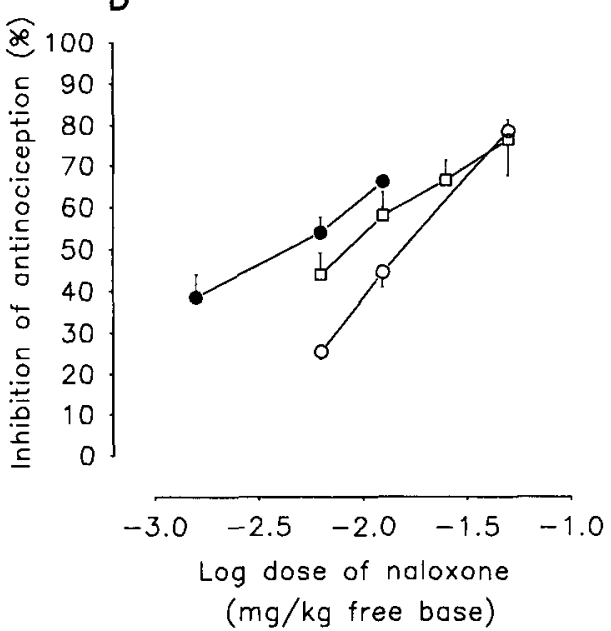

Fig. 4. The time- (A, B and C) and log dose- (D) response curves of the antagonism by s.c. naloxone $(0.00156-0.05 \mathrm{mg} / \mathrm{kg})$ of the antinociceptive effects of i.p. fentanyl $(0.03 \mathrm{mg} / \mathrm{kg}, \mathrm{A}$ and $\mathrm{D}),( \pm)$ cis 3 -carbomethoxy fentanyl $(0.073 \mathrm{mg} / \mathrm{kg}, \mathrm{B}$ and $\mathrm{D})$ and $( \pm)$ trans 3-carbomethoxy fentanyl $(0.29 \mathrm{mg} / \mathrm{kg}, \mathrm{C}$ and $\mathrm{D})$ in rats. A, B and C: naloxone $(0.05 \mathrm{mg} / \mathrm{kg}, \boldsymbol{\Delta} ; 0.025 \mathrm{mg} / \mathrm{kg}, \boldsymbol{\nabla} ; 0.0125$ $\mathrm{mg} / \mathrm{kg}, \square ; 0.00625 \mathrm{mg} / \mathrm{kg}, \diamond ; 0.00156 \mathrm{mg} / \mathrm{kg}, \diamond)$ and saline $(\nabla)$. D: fentanyl $(0.03 \mathrm{mg} / \mathrm{kg}, \square)$, ( \pm ) cis 3-carbomethoxy fentanyl $(0.073 \mathrm{mg} / \mathrm{kg}, 0)$ and $( \pm)$ trans 3 -carbomethoxy fentanyl $(0.29 \mathrm{mg} / \mathrm{kg}, \bigcirc) . \mathrm{MPE}=$ maximum possible effect (antinociception). Each point represents the mean \pm S.E.M. of the effects obtained in six to eight rats.

Table 2. Summary of $\mathrm{ID}_{50}$ and slope values for the dose-dependent antagonism by s.c. naloxone of the antinociceptive effects of i.p. fentanyl, $( \pm)$ cis 3-carbomethoxy fentanyl and $( \pm)$ trans 3 -carbomethoxy fentanyl in rats ${ }^{1}$

\begin{tabular}{lccc}
\hline & $\begin{array}{c}\text { Fentanyl } \\
\left(0.03 \begin{array}{c}\mathrm{mg} / \mathrm{kg}, \mathrm{i} . \mathrm{p} .)^{2} \\
(\mathrm{n}=30)\end{array}\right.\end{array}$ & $\begin{array}{c}( \pm) \text { cis 3-Carbomethoxy fentanyl } \\
(0.073 \mathrm{mg} / \mathrm{kg}, \mathrm{i.p.})^{2} \\
(\mathrm{n}=\mathbf{2 0})\end{array}$ & $\begin{array}{c}( \pm) \text { trans 3-Carbomethoxy fentanyl } \\
(0.29 \mathrm{mg} / \mathrm{kg}, \mathrm{i} . \mathrm{p} .)^{2} \\
(\mathrm{n}=23)\end{array}$ \\
\hline $\mathrm{ID}_{50}(\mathrm{mg} / \mathrm{kg})$ & 0.008 & 0.004 & 0.016 \\
$95 \% \mathrm{CL}$ & $(0.005-0.013)$ & $(0.001-0.016)$ & $(0.011-0.022)$ \\
slope & $35 \pm 3.5$ & $30.1 \pm 3.7$ & $58.6 \pm 1.8^{*}$ \\
$\mathrm{r}$ & 0.990 & 0.993 & 1 \\
\hline
\end{tabular}

${ }^{1}$ Results are summarized from data presented in Fig. 4D. ${ }^{2}$ The lowest dose of compound given i.p. that produces the maximum possible antinociceptive effect $=\mathrm{ED}_{99}$ (see Fig. $3 \mathrm{~A}, \mathrm{~B}$ and $\mathrm{C}$ for the antinociceptive effects of the respective doses). $\mathrm{n}=$ number of animals required to produce the naloxone antagonism curve. Each naloxone antagonism curve was constructed from at least three doses of naloxone with 6-8 rats per naloxone dose. *Significantly $(P<0.05)$ different in comparison with fentanyl and $( \pm)$ cis 3-carbomethoxy fentanyl. 
findings of Van Bever et al., as well as the results of our preliminary investigation of a series of newly synthesized 3alkyl fentanyl analogues, it is evident that 3-carbomethoxy fentanyl is far less active than 3-methyl and 3-ethyl fentanyl $(18,20)$. Otherwise, it seems that $( \pm)$ cis 3-carbomethoxy fentanyl is equipotent to the $( \pm$ )cis 3-propyl fentanyl and exceeds the potency of $( \pm$ ) cis 3-allyl fentanyl, $( \pm$ ) cis 3butyl fentanyl, as well as $( \pm)$ cis 3-benzyl fentanyl (4, 18, 21). Based on the study of SAR of 3-alkyl fentanyl analogues, it has been previously concluded that the antinociceptive activity of 3-alkyl fentanyl analogues depends on the voluminosity of the alkyl group and the cis/trans isomerism $(4,18)$. The difference in the activity between $( \pm$ ) cis and $( \pm$ )trans 3-carbomethoxy fentanyl, observed in this study, parallels such examples, since the cis isomer is about 4 times more active than the trans one (Table 1). In addition, since no functionality is present in the case of 3propyl fentanyl, the observed similarity in antinociceptive potency would result exclusively from the similar voluminosity of the 3-propyl and 3-carbomethoxy group. Consequently, it seems that a steric factor had a predominant role in the antinociceptive potency of 3-substituted fentanyl analogues, while the nature of the substituent was probably irrelevant. Furthermore, based on the available information on the pharmacological properties of 4-carbomethoxy fentanyl, it is evident that $( \pm$ ) cis 3-carbomethoxy fentanyl is considerably (about 60 times) less potent in comparison with its regioisomer, carfentanil (22). Here again, the influence of steric factor is confirmed, since there is no difference in functional groups between 3-carbomethoxy and 4-carbomethoxy fentanyl. Therefore, the main conclusion in this research was that the antinociceptive potency of 3-carbomethoxy fentanyl is independent of the nature of the substituent group, i.e., it is influenced by the steric factor only. Nevertheless, it is still possible that the reduced potency of 3-carbomethoxy fentanyl is a result of altered pharmacokinetic properties.

On the other hand, it is evident that 3-carbomethoxy group provides more rapid onset and shorter duration of action. Because the length of surgical procedures is often unpredictable and because the level of surgical stimulation against which the depth of anesthesia must be balanced is highly variable, the advantages of predictably short-acting alfentanil and remifentanil in comparison with fentanyl have already been shown $(12,33)$. In addition, their rapid onset of action allows fast curtailment of an evoked cardiovascular stress response during anesthesia for surgery $(12,33)$. Therefore, the rapid onset and offset of effects of opioid analgesics are preferable characteristics in anesthesia that enable precise tailoring of analgesia to the prevailing surgical conditions. At the doses producing comparable changes in the antinociceptive response measures, $( \pm)$ cis and $( \pm$ )trans 3 -carbomethoxy fentanyl produced effects that were substantially shorter as compared with the effects produced by fentanyl. In contrast to potency, the time course of action is not significantly influenced by stereochemistry; i.e., cis or trans. At present, we can only speculate that the difference in the time of onset, as well as duration of action after i.p. administration of all tested compounds, probably results from the differences in their physicochemical characteristics and/or metabolism. It has already been observed that the more hydrophilic or ionized substituents lead to analgesics with less lipid solubility (lower partition coefficients), little or no accumulation in fat tissues, and rapid excretion (33). Therefore, in contrast to potency, the influence of chemical nature of the carbomethoxy group upon the onset and the duration of antinociceptive activity is more probable. For example, shorter action of both isomers of 3-carbomethoxy fentanyl could also be due to susceptibility of the carbomethoxy group to rapid hydrolysis by non-specific esterases, such as is the case with the ultra-short-acting fentanyl analogue remifentanil (10). To test this hypothesis, further pharmacological investigation is necessary. In addition, drug-receptor interaction could also have an influence on the onset and duration of effects, as it has already been shown in the case of alfentanil (11), bruprenorphine (34) or (+)cis 3-methyl fentanyl (35).

In this study, time-response curves for antinociception were determined for each test compound in the absence and in the presence of increasing doses of naloxone (Fig. 4: A, B and C). Since both $( \pm)$ cis and $( \pm$ )trans 3-carbomethoxy fentanyl were sensitive to naloxone antagonism, it was concluded that the antinociceptive effects of 3-carbomethoxy fentanyl is opioid-receptor-mediated.

In accordance with the experiments done using fentanyl i.p. in rats $(36,37)$ the side effects of $( \pm)$ cis 3-carbomethoxy fentanyl and $( \pm)$ trans 3 -carbomethoxy fentanyl observed in our study were morphine-like; i.e., characterized by stiffness of the tail, catalepsy, loss of righting reflex, loss of the pinna reflex, etc. Doses that are 2-3 times higher than those required to produce complete block on the tailimmersion test were commonly associated with a loss of pinna reflex and tail stiffness, while much higher doses produced a significant increase in the incidence of catalepsy and loss of righting reflex. It should be stressed, however, that the doses of all three compounds needed to produce maximal antinociception did not have any significant effect on motor the function, nor was any death observed during the following 7 post-treatment days.

The slope of the dose-response curve for antinociception of 3-carbomethoxy fentanyl in the tail-immersion test at $55^{\circ} \mathrm{C}$ was linear and steep, although shallower compared to fentanyl (38). This finding taken together with: 1) considerable potency in thermal test using high intensity of stimuli $(28,39,40), 2)$ fentanyl-like profile of behavior effects $(36)$, and 3 ) great sensitivity to antagonism by naloxone (2) im- 
plies that 3-carbomethoxy fentanyl produces effects in a similar manner as fentanyl, most probably through the action on $\mu$-opioid receptors. To test this hypothesis, further work by using selective antagonists of opioid receptors is required.

Since the antinociceptive activity of the 4-anilidopiperidine analogues is usually highly dependent on stereochemistry, it is probable that one enantiomer of both tested compounds will be more active than the tested racemic mixture.

The synthesis and the pharmacological evaluation of 3carbomethoxy fentanyl will provide better understanding of SAR of 3-substituted fentanyl analogues. Based on the results obtained in these studies, it is concluded that the steric factor has a predominant role in the antinociceptive potency of 3-substituted fentanyl analogues, while the nature of the substituent is probably irrelevant. In addition, it was revealed that 3-carbomethoxy fentanyl is not especially potent, neither selective in comparison with fentanyl, but is notable for its short duration of action. Unfortunately, so far pharmacokinetics of 3-carbomethoxy fentanyl have not been evaluated, so the closer SAR could not be determined. Nevertheless, in view of the present findings, this novel antinociceptive compound appears to be worthy of further study.

\section{REFERENCES}

1 Cherny NI: Opioid analgesics. Comparative features and prescribing guidelines. Drugs 51, $713-737$ (1996)

2 Reisine T and Pasternak G: Opioid analgesics and antagonists. In Goodman \& Gilman's The Pharmacological Basis of Therapeutics, Edited by Hardman JG, Limbird LE, Molinoff PB, Ruddon RW and Gilman AG, 9th international edition, pp 521-555, McGraw-Hill (Health Professions Division), New York (1996)

3 Peng PW and Sandler AN: A review of the use of fentanyl analgesia in the management of acute pain in adults. Anesthesiology 90, 576-599 (1999)

4 Casy AF and Parfitt RT: Fentanyl and the 4-anilinopiperidine group of analgesics. In Opioid Analgesics: Chemistry and Receptors, pp 287-301, Plenum Press, New York and London (1986)

5 Bagley JR, Kudzma LV, Lalinde NL, Colapret JA, Huang B-S, Lin B-S, Jerussi TP, Benvenga MJ, Doorley BM, Ossipov MH, Spaulding TC, Spencer HK, Rudo FG and Wynn RL: Opioid analgesics. Med Res Rev 11, 403 - 436 (1991)

6 Portoghese PS: The role of concepts in structure-activityrelationship studies of opioid ligands. J Med Chem 35, 1927 1937 (1992)

7 Gerak LR, Moerschbaecher JM, Bagley JR, Brockunier LL and France CP: Effects of a novel fentanyl derivative on drug discrimination and learning in rhesus monkeys. Pharmacol Biochem Behav 64, 367-371 (1999)

8 Bi-Yi C, Wen-Qiao J, Jie C, Xin-Jian C, You-Cheng Z and ZhiQiang C: Analgesic activity and selectivity of isothiocyanate derivatives of fentanyl analogs for opioid receptors. Life Sci $\mathbf{6 5}$, $1589-1595$ (1999)
9 Niemegeers CJE, Schellekens KHL, Van Bever WFM and Janssen PAJ: Sufentanil, a very potent and extremely safe intravenous morphine-like compound in mice, rats and dogs. Arzneimittelforschung 26, 1551 - 1556 (1976)

10 Feldman PL, James MK, Brackeen MF, Bilotta JM, Schuster SV, Lahey AP, Lutz MW, Johnson MR and Leighton HJ: Design, synthesis, and pharmacological evaluation of ultrashort- to longacting opioid analgesics. J Med Chem 34, $2202-2208$ (1991)

11 Cookson RF, Niemegeers CJE and Bussche GV: The development of alfentanil. Br J Anaesth 55, 147S - 155S (1983)

12 Patel SS and Spencer CM: Remifentanil. Drugs 52, 417-427 (1996)

13 France CP, Ahn SC, Brockunier LL, Bagley JR, Brandt MR, Winsauer PJ and Moerschbaecher JM: Behavioral effects and binding affinities of the fentanyl derivative OHM3507. Pharmacol Biochem Behav 59, 295 - 303 (1998)

14 Subramanian G, Paterlini MG, Portoghese PS and Ferguson DM: Molecular docking reveals a novel binding site model for fentanyl at the mu-opioid receptor. J Med Chem 43, 381-391 (2000)

15 Lu YF, Xu H, Liu-Chen LY, Chen C, Partilla JS, Brine GA, Carroll FI, Rice KC, Lai J, Porreca F, Sadee W and Rothman RB: Opioid peptide receptor studies. The methylfentanyl congener RTI-4614-4 and its four enantiomers bind to different domains of the rat mu opioid receptor. Synapse 28, 117-124 (1998)

16 Gauthier CA, Bagley JR, Brockunier LL and France CP: Daily mirfentanil induces (cross-) tolerance to the rate-decreasing effects of morphine and not mirfentanil. Behav Pharmacol 10, $543-547$ (1999)

17 Mićović IV, Ivanović MD, Vučković SM, Prostran MŠ, DošsenMićović LJ and Kiricojević VD: The synthesis and preliminary pharmacological evaluation of 4-methyl fentanyl. Bioorg Med Chem Lett 10, 2011 - 2014 (2000)

18 Vučković S, Prostran M, Todorović $Z$, Grbović L, Ivanović M, Stojanović R and Matić I: Analgesic activity of 3-alkyl fentanyl analogues in rats: Structure-activity study. Fundam Clin Pharmacol 13, Suppl 1, 212S (1999)

19 Riley TN, Hale DB and Wilson MC: 4-Anilidopiperidine analgesics. I: synthesis and analgesic activity of certain ring-methylated 1-substituted 4-propananilidopiperidines. J Pharm Sci 62, 983 986 (1973)

20 Van Bever WFM, Niemegeers CJE and Janssen PAJ: Synthetic analgesics. Synthesis and pharmacology of the diastereoisomers of $\quad N$-[3-methyl-1-(2-phenylethyl)-4-piperidyl]- $N$-phenylpropanamide and $N$-[3-methyl-1-(1-methyl-2-phenylethyl)-4-piperidyl]- $N$ phenylpropanamide. J Med Chem 17, 1047 - 1051 (1974)

21 Casy AF and Ogungbamila FO: 3-Allyl analogues of fentanyl. J Pharm Pharmacol 34, 210 (1982)

22 Van Daele PGH, De Bruyn MFL, Boey JM, Sanezuk S, Agten JTM and Janssen PAJ: Synthetic analgesics: $N$-(1-[2-arylethyl]-4substituted 4-piperidinyl) $\mathrm{N}$-arylalkanamides. Arzneimittelforschung 26, 1521 - 1531 (1976)

23 De Vos V: Immobilisation of free-ranging wild animals using a new drug. Vet Rec 103, 64-68 (1978)

24 Caulkett NA, Cribb PH and Haigh JC: Comparative cardiopulmonary effects of carfentanil-xylazine and medetomidine-ketamine used for immobilization of mule deer and mule deer/whitetailed deer hybrids. Can J Vet Res 64, 64-68 (2000)

25 De Castro J, Van de Water A, Wouters L, Xonneux R, Reneman 
R and Kay B: Comparative study of cardiovascular, neurological and metabolic side-effects of eight narcotics in dogs. Acta Anaesth Belg 30, 5-99 (1979)

26 Mićović IV, Ivanović MD, Vučković S, Jovanović-Mićić D, Beleslin D, Došen-Mićović Lj and Kiricojević VD: 3-Carbomethoxy fentanyl: synthesis, pharmacology and conformational analysis. Heterocycl Commun 4, $171-179$ (1998)

27 Janssen PAJ, Niemegeers CJE and Dony JGH: The inhibitory effect of fentanyl and other morphine-like analgesics on the warm water induced tail withdrawal reflex in rats. Arzneimittelforschung 13, 502-507 (1963)

28 Abbott FV, Franklin BJ and Libman RB: A dose-ratio comparison of mu and kappa agonists in formalin and thermal pain. Life Sci 39, 2017- 2024 (1986)

29 Tallarida RJ and Murray RB: Manual of Pharmacologic Calculations with Computer Programs, 2nd edition, Springer Verlag, New York (1986)

30 Smits SE and Takemori AE: Quantative studies on the antagonism by naloxone of some narcotic and narcotic-antagonist analgesic. Br J Pharmacol 39, 627-638 (1970)

31 Lawson JA, Cheng A, DeGraw J, Frenking G, Uyeno E, Toll L and Loew GH: Effects of addition of a 2-methyl group to ethyl nipecotates ( $\beta$-meperidines) on receptor affinities and opiate agonist/antagonist activities. J Med Chem 31, 2015 - 2021 (1988)

32 Yaksh TL, Noueihed RY and Durant PAC: Studies of the pharmacology and pathology of intrathecally administered 4anilinopiperidine analogues and morphine in the rat and cat. Anesthesiology 64, 54-66 (1986)
33 Scholz J, Steinfath $M$ and Schulz M: Clinical pharmacokinetics of alfentanil, fentanyl and sufentanil. An update. Clin Pharmacokinet 31, 275 - 292 (1996)

34 Cowan A, Lewis JW and Macfarlane IR: Agonist and antagonist properties of buprenorphine, a new antinociceptive agent. $\mathrm{Br} \mathrm{J}$ Pharmacol 60, 537 - 545 (1977)

$35 \mathrm{Xu} \mathrm{H}$, Kim C-H, Zhu YC, Weber RJ, Jacobson AE, Rice KC and Rothman RB: $(+)$-cis-3-Methylfentanyl and its analogs bind pseudoirreversibly to the mu opioid binding site: evidence for pseudoallosteric modulation. Neuropharmacology 30, 455-462 (1991)

36 Ivanović MD, Vučković S, Ristović Z, Mićović IV and Beleslin DB: Behavioural effects of fentanyl in rats. Iugoslav Physiol Pharmacol Acta 31, 195 - 199 (1995)

37 Vučković S, Ivanović M, Prostran M, Todorović Z, Ristović Z, Mićović I and Beleslin D: Higher environmental temperature potentiates cataleptic effect of fentanyl in rats. Jpn J Pharmacol 78, 523 - 527 (1998)

38 Sewel RDE and Spencer PSJ: Antinociceptive activity of narcotic agonist and partial agonist analgesics and other agents in the tailimmersion test in mice and rats. Neuropharmacology 15, $683-$ 688 (1976)

39 Cowan A: Recent approaches in the testing of analgesics in animals. In Modern Methods in Pharmacology, Edited by Adler MW and Cowan A, Vol 6, Testing and Evaluation of Drugs of Abuse, pp 33 - 42, Wiley-Liss, Inc, New York (1990)

40 Tyers MB: A classification of opiate receptors that mediate antinociception in animals. Br J Pharmacol 69, 503-512 (1980) 